\title{
Penerapan Model RAD Pada Perancangan Sistem Informasi Pendaftaran Mutasi Penduduk Disdukcapil Kota Bogor
}

\author{
Sismadi \\ Universitas Bina Sarana Informatika \\ e-mail: sismadi.ssm@bsi.ac.id

\begin{tabular}{ccc}
\hline Diterima & Direvisi & Disetujui \\
$09-12-2020$ & $12-01-2021$ & $25-01-2021$ \\
\hline
\end{tabular}

\begin{abstract}
Abstrak - Pelayanan umum khususnya berhubungan langsung dengan penduduk sangat penting dijaga kualitas pelayanan. Selain kualitas, kecepatan dan ketepatan sangat dibutuhkan sebagai tolak ukur keberhasilan suatu badan pemerintah. Pendataan penduduk suatu daerah harus tepat dan akurat, begitu pula pelayanan pendaftaran mutasi penduduk harus tepat serta akurat dalam proses pencatatan. Dinas Kependudukan dan pencatatan sipil kota bogor masih dilakukan secara manual, sehingga timbul beberapa permasalahan. Pertama tidak standarnya kualitas tulisan tangan petugas yang ada, setiap petugas memiliki model tulisan sendiri. Bermula dari tulisan tangan menimbulkan persepsi yang berbeda dibagian lain, sehingga pencatatan data yang tidak akurat. Ketidak akuratan data yang masuk menyebabkan proses pendataan mutasi kedatangan dan pindah jiwa memakan waktu lebih lama dari seharusnya. Permasalahan kedua, dengan pencatatan yang manual menimbulkan penumpukan dokumen penduduk sehingga membutuhkan tempat untuk penyimpanan dan kemungkinan data hilang ataupun rusak menjadi sangat mungkin. Untuk memecahkan permasalahan ini, dibutuhkan solusi yang tepat dengan mentransformasi kedalam pencatatan digital. Pencatatan yang dilakukan adalah penduduk yang akan mutasi mengisi data secara mandiri melalui sarana sistem yang bersifat online. Hal ini dilakukan mengingat masa pandemic corona belum berakhir, sehingga wajib untuk menghindari kerumunan manusia. Sistem yang dibangun menggunakan model $R A D$, framework codeigniter yang berbasis $M V C$ dan bersifat object oriented programming. Hasil dari transformasi manual kedigital dapat meningkatkan kualitas pelayanan mutasi penduduk lebih akurat, cepat dan efisien serta dapat membantu memutus rantai penyebaran covid19.
\end{abstract}

Kata Kunci: Pelayanan Mutasi Penduduk, Penerapan Model Rad, Sistem Informasi Mutasi Penduduk

Abstract -Public services, especially those dealing directly with the population, are very important to maintain the quality of service. Apart from quality, speed and accuracy are needed as benchmarks for the success of a government agency. Data collection on the population of an area must be precise and accurate, as well as registration services for population mutations must be precise and accurate in the recording process. The Department of Population and civil registration of the city of Bogor is still being carried out manually, so that several problems arise. First, the quality of the staff's handwriting is not standard, each officer has their own writing model. Starting from handwriting, it creates a different perception in other parts, resulting in inaccurate data recording. The inaccuracy of the incoming data causes the data collection process for the arrival and transfer of souls to take longer than it should be. The second problem is that manual recording causes accumulation of resident documents so that it requires a place for storage and the possibility of data being lost or damaged is very possible. To solve this problem, we need the right solution by transforming into digital recording. The recording that will be carried out is the population who will mutate filling in data independently through an online system. This is done considering that the corona pandemic has not ended, so it is mandatory to avoid crowds of people. The system is built using the RAD model, a codeigniter framework based on MVC and object oriented programming. The results of manual digital transformation can improve the quality of population transfer services more accurately, quickly and efficiently and can help break the chain of the spread of Covid19.

Keywords: Population Mutation Service, Application of Rad Model, Population Mutation Information System 


\section{PENDAHULUAN}

Kota bogor yang terletak $59 \mathrm{~km}^{2}$ disebelah selatan jakarta, memiliki 6 kecamatan dan 68 kelurahan. Penduduk mayoritas suku sunda dan berjumlah 1,013,019 jiwa pada tahun 2017. Dinas kependudukan dan pencatatan sipil kota bogor terletak di Jl. Ahmad Adnawijaya No.45 A Tegal Gundil, Bogor Utara, Kota Bogor.

Penyelenggaraan pelayanan kepada masyarakat khususnya bagian pendaftaran atau mutasi penduduk masih dilaksanakan secara manual, sedangkan jumlah penduduk yang harus dilayani sedemikian besar. Pelayanan publik merupakan kegiatan untuk pemenuhan kebutuhan pelayanan sesuai undangundang yang berlaku dapat dilaksanankan secara manual atapun dengan bantuan elektronik(“Undang Undang No.25 Tahun 2009 Tentang Pelayanan Publik," 2009).

Pelayan yang dilaksanakan oleh dinas kependudukan dan pecatatan sipil kota bogor masih bersifat manual, ditulis tangan dalam bentuk formulir dengan isian yang cukup banyak, hal ini menimbulkan permasalahan yaitu tidak standar model tulisan yang ada pada formulir sebab setiap petugas memiliki model tulisan sendiri dan unik, sehingga menimbulkan interpretasi yang berbeda dibagian penginputan data. Efek dari hal ini menyebabkan pelayanan pendaftaran dan pindah jiwa menjadi lebih lama dari yang seharusnya, sehingga kualitas dan efektifitas pelayanan menurun. Selain itu ketidak akuratan informasi yang ada pada formulir menyebabkan kesalahan data bagi masyarakat yang sedang membutuhkan. Akibat dari hal ini masyarakat harus datang kembali untuk melakukan perbaikan data, sehingga harus bekerja dua kali. Dari sisi fisik dengan pelayanan manual berbasis kertas menimbulkan penumpukan dokumen sehingga membutuhkan tempat khusus penyimpanan dan resiko dokumen rusak serta hilang.

Untuk pemecahan permasalahan ini harus dibuat terobosan baru yaitu melakukan digitalisasi pelayanan, peneliti menawarkan pemecahan persoalan dengan membangun sistem informasi pencatatan mutasi penduduk dengan basis online. Dengan cara ini permasalahan penumpukan dokumen dapat diatasi dan kemungkinan kesalahan data yang terdapat diformulir dapat diminimalisasi sebab yang melakukan pencatatan adalah pemohon mutasi penduduk, baik itu kedatangan ataupun pindah jiwa. Sistem yang dibangun menggunakan basis web server, sistem yang akan dibangun dengan framework codeigniter berbasis MVC(modelling view control) dan bersifat OOP. Pemilihan famework codeigniter dengan pertimbangan bahwa framework ini sangat fleksibel terhadap sistem operasi dan kemudahan dalam proses pengembangan sistem(Naik \& Naik, 2019).

Untuk model pengembangan sistem digunakan model RAD(Rapid Application Development). Dengan model ini waktu yang dibutuhkan menjadi lebih singkat $50 \%$ dibanding dengan metode lain, misal waterfall (Mishra \& Dubey, 2013). Model $R A D$ selain cepat dalam pengembangan juga adaptif terhadap perubahan permintaan pengguna(Dhanotia \& Goyal, 2012).

Berikut penelitian terdahulu yang berkorelasi dengan penelitian ini, antara lain;

Model $R A D$ telah digunakan sebagai pengembangan sistem untuk pelatihan pelajar dan mahasiswa sebagai bekal untuk bekerja dimasa depan, sistem yang dibangun dengan target untuk mengatur penjadwalan pelatihan secara terkomputerisasi, dimana pada proses sebelumnya dengan cara manual. Model $R A D$ dipilih dengan pertimbangan bahwa sistem yang dibuat dapat segera diimplementasikan dilingkungan kampus. Sistem dibangun pada pertengahan semester antara desember hingga april 2009 dan terus dikembangankan secara berulang berdasarkan permintaan pengguna(Daud \& Rusli, 2010).

Pada penelitian yang dilakukan oleh Rosa delima, Halim budi santoso dan Joko purwadi membangun web sistem dutatani dengan model $R A D$, hal ini ditempuh dengan pertimbangan bahwa model $R A D$ mengurangi banyak waktu dalam pembangunan sistem. Dutatani adalah portal sistem informasi pertanian yang terintegrasi dengan subsistem lainnya, dimana dapat mengatur pengguna, mengatur isi produk pertanian dan mengatur link yang teritegrasi pada dutatani. Portal dutatani dibangun selama 6 bulan dengan 5 anggota programmer terbagi dengan 2 tim(Delima, Santosa, \& Purwadi, 2017).

Implementasi $R A D$ model juga digunakan pada pembuatan sistem aplikasi pembelajaran 3D berbentuk animasi tentang sistem tata surya untuk anak sekolah dasar, hal ini agar objek yang dipelajari terlihat lebih menarik sehingga minat belajar anak meningkat. Pada sistem ini juga disediakan fitur quis sebagai latihan untuk mengukur tingkat keberhasilan pembelajaran setelah anak belajar dengan sistem yang dibangun ini(Suhartono et al., 2018).

Penelitian terbaru tentang penerapan model $R A D$ juga dapat digunakan pada tata niaga secara online, pada penelitian ini sistem yang dibangun ditujukan sebagai sarana berniaga secara online ditengah maraknya pandemi covid19. Sasaran objek implementasi adalah UMKN dimana pedagang bermodal kecil, sehingga sangat efektif dalam segi 
biaya pengembangan sistem dan segera dapat diimplementasikan(Sismadi, 2020).

Pada penelitian ini selain menggunakan framework codeigniter juga didukung tool lain, diantaranya ajax jquery, bootstraps dan java script. Untuk enginee database menggunakan MySql. Enginee ini bersifat $G P L$ dan juga sudah terbukti mampu menangai data hingga ratusan ribu record, tuntutan spesifikasi mesin yang cukup rendah dan dapat berjalan dengan baik(Mueller, 2020).

\section{METODOLOGI PENELITIAN}

Pada penelitian ini, metode pengumpulan data dengan melakukan observasi keobjek penelitian yaitu dinas kependudukan dan pencatatan sipil kota bogor yang terletak di Jl. Ahmad Adnawijaya No.45 A Tegal Gundil, Bogor Utara, Kota Bogor. Disana melakukan pengamatan cara kerja petugas pendaftaran kedatangan dan pindah jiwa atau mutasi penduduk, serta melakukan wawancara langsung tentang kendala yang dihadapi. Dari hasil pengamatan dan wawancara dapat disimpulkan bahwa permasalahan utama masih manualnya pengisian data mutasi, dengan banyaknya formulir yang ada dan ditulis tangan secara manual, dimana setiap petugas memiliki model tulisan dan ketelitian yang berbeda-beda, sehingga terjadi masalah saat data berada di bagian penginputan. Bila terjadi kesalahan input maka data mutasi menjadi tidak akurat dan menimbulkan keluhan bagi penduduk yang mengajukan mutasi. Dari kondisi tersebut maka alur kerja mutasi data kependudukan menjadi lebih lama dari yang seharusnya. Permasalahan kedua dengan pencatatan manual berdampak pada penumpukan dokumen mutasi warga dan membutuhkan tempat untuk penyimpanan, selain resiko data hilang ataupun rusak.

Berikut kerangka penelitian yang ditempuh pada penelitian ini.

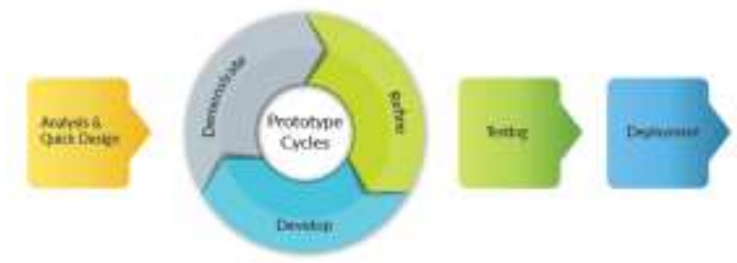

Sumber: Pressman(2010)

\section{Gambar 1. Model RAD}

Langkah-langkah pada model $R A D$ terdapat tiga bagian utama(Ifeanyi Cosmas, 2018).
1. Perencanaan
syarat-syarat(requirements planning)
Pada fase ini pengguna dan analis bertemu untuk mendefinisikan kebutuhan dan syarat yang mendukung tujuan dari pembangunan sistem. Target dari fase ini untuk memecahkan

masalah yang dihadapi dan memperoleh solusi terbaik. Pada penelitian ini permasalahan utama pencatatan mutasi penduduk masih manual dan mengakibatkan permasalahan baru dan penumpukan dokumen yang semakin bertambah setiap harinya, hal ini juga didukung banyaknya penduduk yang mobile dalam bekerja sesuai penugasan perusahaan. Dengan mengubah pola kerja dari manual ke digitalisasi diharapkan kendala yang dihadapi terpecahkan dengan baik dan pola kerja disdukcapil kota bogor menjadi lebih efisien dan efektif serta akurat dalam pendataannya.

Berikut kebutuhan dari pengguna:

a. Kebutuhan pengguna(pengelola dan pengguna)

Pengelola sistem

1. Akses sistem hanya petugas yang berhak.

2. Petugas dapat melakukan perubahan data bila diperlukan

3. Petugas dapat membuat laporan setiap periode tertentu

4. Petugas dapat mendelivery data kebagian lain yang berkaitan

Pengguna(masyarakat)

1. Pengguna dapat mendaftar kesistem

2. Pengguna dapat mengisi form ajuan mutasi data ketempat baru

3. Pengguna dapat mengajukan mutasi/kedatangan kewilayah sesuai tempat yang dituju.

4. Pengguna mendapat notifikasi perkembangan dokumen ajuan

b. Kebutuhan sistem mutasi penduduk

1. Sistem dapat berkomunikasi dan terintegrasi dengan bagian lain

2. Sistem dapat memberikan informasi perkembangan ajuan dokumen mutasi

3. Sistem memiliki pengguna tertentu sesuai hak akses

4. Sistem dapat memberikan laporan pada periode tertentu

5. Sistem dapat mudah dikembangkan sesuai permintaan untuk waktu yang akan datang

2. Workshop desain RAD(RAD Design Workshop) Pada bagian desain workshop ini pengguna, analis dan pemrogram berkeja sama. Analis dan pemrogram mewujudkan desain visual sesuai permintaan pada bagian sebelumnya dan memberikan kepada pengguna, kemudian memperoleh feedback dan berdasarkan masukan tersebut analis dan pemrogram memperbaiki serta mengembangkan desain visual dan fitur yang diinginkan pengguna. Proses pada bagian ini dapat berlangsung beberapa hari tergantung scope sistem yang dibuat. Berikut desain visual yang dikembangkan pada penelitian ini. 


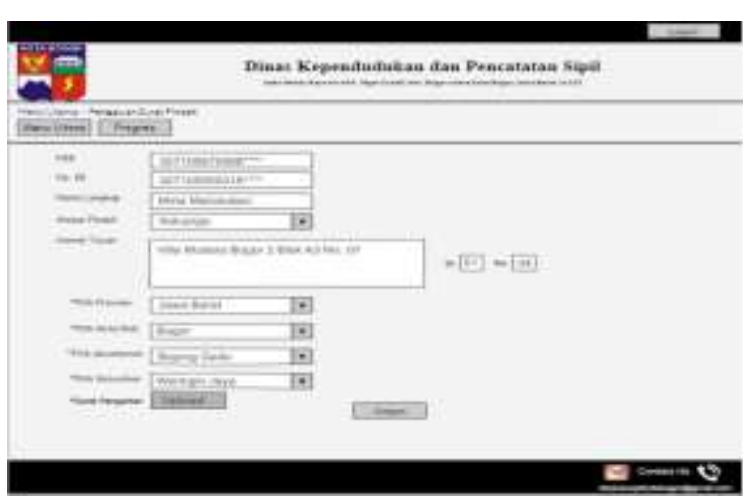

Sumber: Sismadi(2020)

Gambar 2. Desain visual pengajuan surat pindah

Pengajuan visual ini diskusikan beberapa kali bersama pengguna untuk mendapat kenyamanan visual dan kemudahan operasional.

\section{Implementasi(implementation)}

Fase ketiga analis bekerja lebih intens bersama pengguna untuk merencanakan aspek-apek bisnis dan non-teknis institusi untuk dapat disepakati bersama, setelah terdapat kesepakatan maka sistem dibangun(coding). Pembagunan sistem selesai secara umum dan dapat disosialisasikan keinstitusi dan pengguna lainnya.

Untuk pengujian sistem yang telah dibangun, untuk melihat fleksibilitas dan kesesuaian permintaan dari pengguna serta kesesuaian dengan kebutuhan sistem. Pengujian dengan metode blackbox(Nidhra \& Dondeti, 2012). Berikut tabel pengujian blackbox test untuk pengajuan surat pindah jiwa.

Tabel 1. Black Box testing pengajuan surat pindah jiwa

\begin{tabular}{|c|c|c|c|c|}
\hline No & Aktifitas & $\begin{array}{c}\text { Realisasi } \\
\text { yang } \\
\text { diharapkan }\end{array}$ & $\begin{array}{c}\text { Hasil } \\
\text { pengujian }\end{array}$ & Kesimpulan \\
\hline 1 & Isian KK & $\begin{array}{l}\text { Nomer KK } \\
\text { sudah ada } \\
\text { pada } \\
\text { database } \\
\text { dan } \\
\text { sifatnya } \\
\text { autocomple } \\
\text { te }\end{array}$ & $\begin{array}{c}\text { Autocompl } \\
\text { ete terjadi } \\
\text { dan KK } \\
\text { sesuai } \\
\text { dengan } \\
\text { data real }\end{array}$ & $\begin{array}{l}\text { [X]Diterima } \\
\text { [ ]Ditolak }\end{array}$ \\
\hline 2 & Isian NIK & $\begin{array}{l}\text { Nomer } \\
\text { NIK hasil } \\
\text { repopulasi } \\
\text { dari KK } \\
\text { pada } \\
\text { database }\end{array}$ & $\begin{array}{c}\text { NIK } \\
\text { terdaftar } \\
\text { pada } \\
\text { database }\end{array}$ & $\begin{array}{c}\text { [X]Diterima } \\
\text { [ ]Ditolak }\end{array}$ \\
\hline 3 & $\begin{array}{l}\text { Isian } \\
\text { alasan } \\
\text { pindah }\end{array}$ & $\begin{array}{l}\text { Tercantum } \\
\text { pada } \\
\text { listbox }\end{array}$ & $\begin{array}{c}\text { Pilih sesuai } \\
\text { data real } \\
\text { dan } \\
\text { tersedia }\end{array}$ & $\begin{array}{c}\text { [X]Diterima } \\
\text { [ ]Ditolak }\end{array}$ \\
\hline 4 & $\begin{array}{l}\text { Pilihan } \\
\text { propinsi }\end{array}$ & $\begin{array}{l}\text { Tercantum } \\
\text { pada } \\
\text { listbox }\end{array}$ & $\begin{array}{l}\text { Pilih sesuai } \\
\text { data real } \\
\text { dan }\end{array}$ & $\begin{array}{c}\text { [X]Diterima } \\
\text { [ ]Ditolak }\end{array}$ \\
\hline
\end{tabular}

\begin{tabular}{|c|c|c|c|c|}
\hline & & & tersedia & \\
\hline 5 & $\begin{array}{l}\text { Pilihan } \\
\text { kota/kab }\end{array}$ & $\begin{array}{c}\text { Tercantum } \\
\text { pada } \\
\text { listbox }\end{array}$ & $\begin{array}{l}\text { Pilih sesuai } \\
\text { data real } \\
\text { dan } \\
\text { tersedia }\end{array}$ & $\begin{array}{c}\text { [X]Diterima } \\
\text { [ ]Ditolak }\end{array}$ \\
\hline 6 & $\begin{array}{l}\text { Pilihan } \\
\text { kecamatan }\end{array}$ & $\begin{array}{c}\text { Tercantum } \\
\text { pada } \\
\text { listbox }\end{array}$ & $\begin{array}{c}\text { Pilih sesuai } \\
\text { data real } \\
\text { dan } \\
\text { tersedia }\end{array}$ & $\begin{array}{c}\text { [X]Diterima } \\
\text { [ ]Ditolak }\end{array}$ \\
\hline 7 & $\begin{array}{l}\text { Pilihan } \\
\text { kelurahan/ } \\
\text { desa }\end{array}$ & $\begin{array}{l}\text { Tercantum } \\
\text { pada } \\
\text { listbox }\end{array}$ & $\begin{array}{l}\text { Pilih sesuai } \\
\text { data real } \\
\text { dan } \\
\text { tersedia }\end{array}$ & $\begin{array}{c}\text { [X]Diterima } \\
\text { [ ]Ditolak }\end{array}$ \\
\hline 8 & $\begin{array}{l}\text { Pilih file } \\
\text { yang } \\
\text { diupload }\end{array}$ & $\begin{array}{c}\text { File } \\
\text { dokumen } \\
\text { tidak } \\
\text { dipilih }\end{array}$ & ditolak & $\begin{array}{l}\text { [X]Diterima } \\
\text { [ ]Ditolak }\end{array}$ \\
\hline 9 & $\begin{array}{l}\text { Pilih file } \\
\text { yang } \\
\text { diupload }\end{array}$ & $\begin{array}{c}\text { File } \\
\text { dokumen } \\
\text { dipilih } \\
\text { seuai } \\
\text { aturan } \\
\end{array}$ & diterima & $\begin{array}{l}\text { [X]Diterima } \\
\text { [ ]Ditolak }\end{array}$ \\
\hline
\end{tabular}

Sumber: Sismadi (2020)

Sebelum sistem masuk production maka wajib menjalani proses testing, proses ini biasa disebut dengan UAT. Hal ini dilakukan sebagai bentuk validasi akhir dari pembagunan sistem informasi dapat disebut layak ataupun tidak oleh pengguna(Haris, Jatmiko, \& Wibisono, 2013). Testing akhir dilaksanakan bersama-sama semua tim yang terlibat sebelum masuk ke production. Testing biasa disebut $U A T$ (user acceptance test), bila testing ini telah dilewati dan sesuai dengan permintaan pengguna, maka sistem siap untuk masuk ke production.

Selang beberapa waktu dikaji kembali dan disesuaikan dengan kebutuhan dari pengguna. Proses maintenance dapat terjadi minor ataupun major sesuai dengan feedback dari pengguna.

\section{HASIL DAN PEMBAHASAN}

Penelitian ini menghasilkan desain rancangan dan visual dari sistem yang dibangun berdasarkan alur kerja model $R A D$ serta kesesuaian dengan permintaan pengguna. Berikut hasil rancangan pada tahap satu, yaitu requirements planning, yang digambarkan dengan desain menggunakan tool UML(unified modelling language) dengan mendesain menggunakan use case, diagram activity dan sequence diagram.

Pembangunan sistem ini menghasilkan 2 pengguna, yaitu masyarakat dan petugas disdukcapil. Berikut desain use case hal tersebut.

\section{Pengguna sebagai anggota masyarakat}

Pengguna ini memiliki beberapa fitur, melakukan pedaftaran kemudian dapat login kedalam sistem dengan user berdasarkan NIK, dapat mengubah profil, pengajuan mutasi dan memantau 
perkembangan ajuan mutasi serta keluar dari sistem. Gambar 3. Desain dari kebutuhan warga pada sistem yang dibangun dan menggambarkan fitur yang dimiliki.

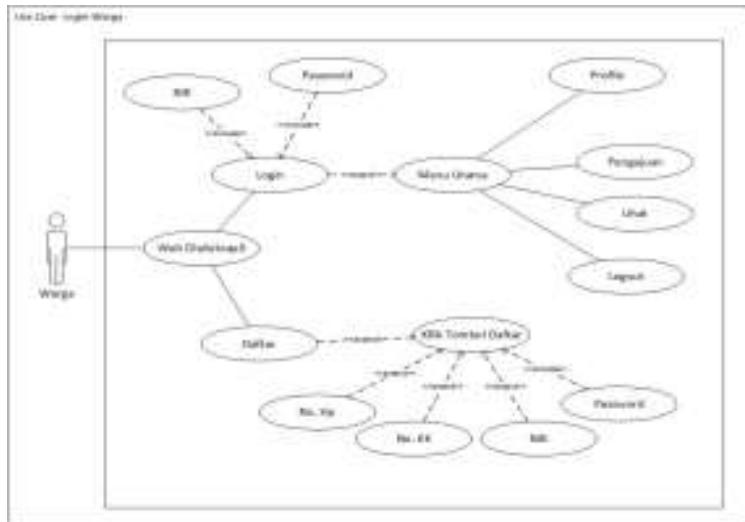

Sumber: Sismadi(2020)

Gambar 3. Use case kebutuhan warga

Berikut gambar 4. use case pengajuan data mutasi atau pindah jiwa ketempat yang baru. Dengan mengisi data pribadi sesuai dokumen dan alamat baru yang akan dituju.

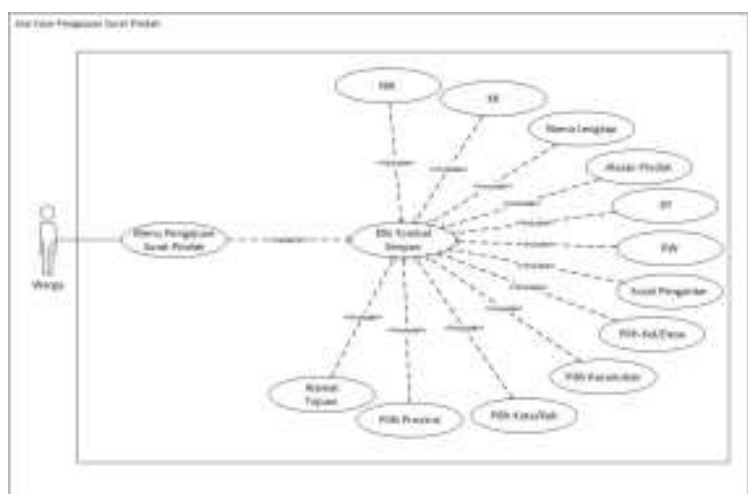

Sumber: Sismadi(2020)

Gambar 4. Use case pengajuan mutasi pindah

Dari desain Use case diatas kemudian dibuat detilnya dengan activity diagram untuk beberapa hal yang penting untuk menggambarkan lebih jelas sistem yang dibangun. Berikut gambar 5. activity diagram daftar untuk masyarakat yang akan mengurus mutasi jiwa. Digambarkan bahwa warga melakukan pengisian data sebagai agregat untuk mendaftarkan diri kedalam sistem.

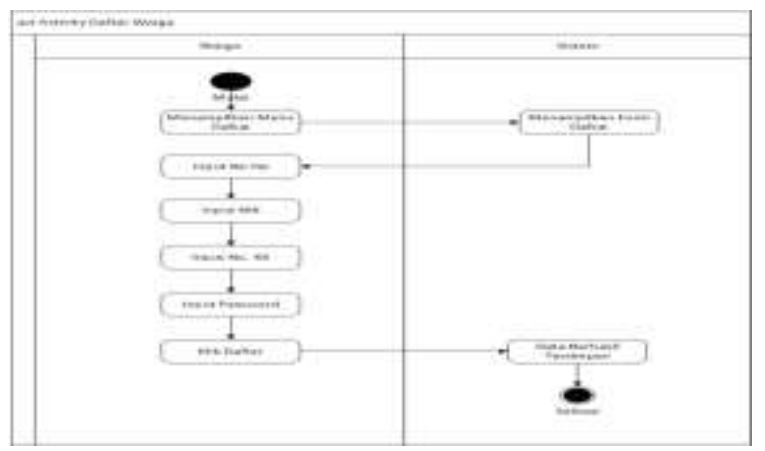

Sumber: Sismadi(2020)

Gambar 5. activity diagram register sistem

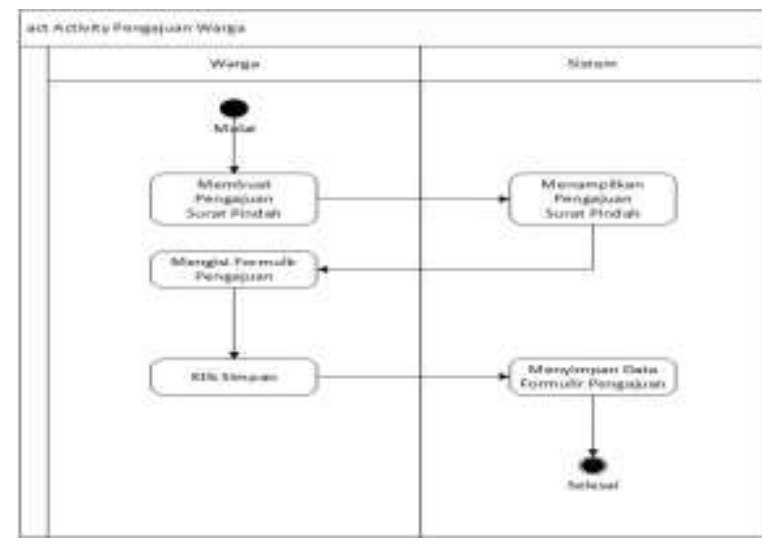

Sumber: Sismadi(2020)

Gambar 6. Activity diagram ajuan mutasi

Pada ajuan mutasi jiwa gambar 6. juga diberikan fitur untuk mengubah ajuan mutase, hal ini disesuaikan permintaan, bila terjadi kesalahan ajuan, warga masih diberikan kesempatan perbaikan data. Berikut desain ubah ajuan yang tergambar pada gambar 7 .

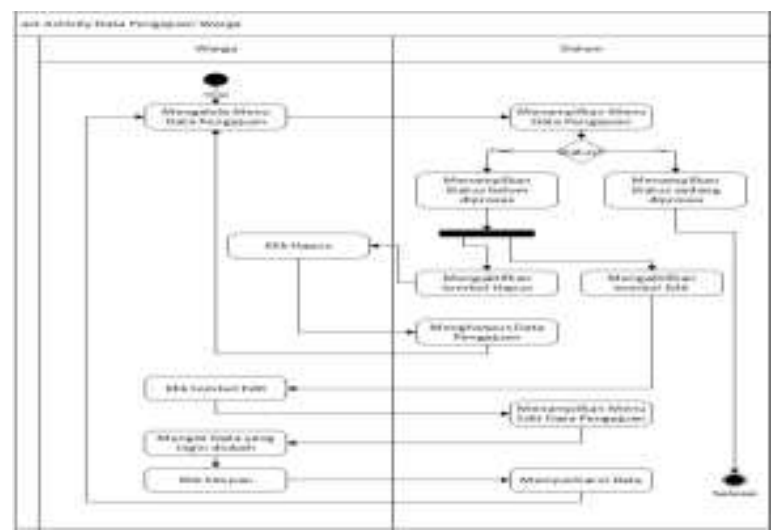

Sumber: Sismadi(2020)

Gambar 7. Activity diagram ubah ajuan mutasi

Gambar 8 menunjukkan alur urutan kerja dari sistem yang dibangun yang tergambar dalam sequence diagram. Alur kerja sistem yang berinteraksi dengan pengguna dalam hal ini warga masyarakat melakukan pendaftaran.

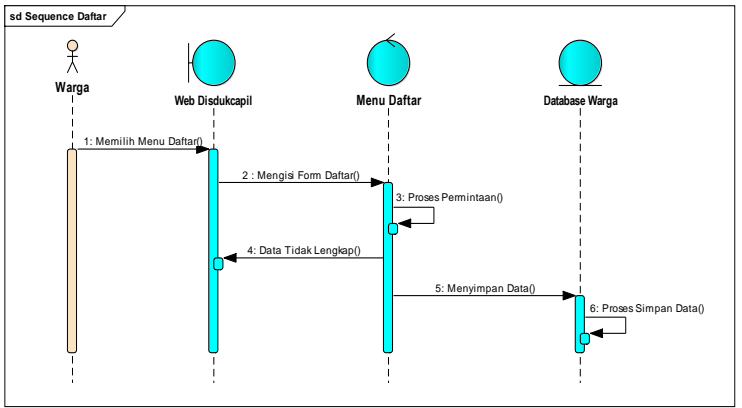

Sumber: Sismadi(2020)

Gambar 8. Sequence diagram pendaftaran 
Pada gambar 9. Menunjukkan kronologi pengajuan mutase jiwa dari warga yang akan berpindah secara administrative maupun secara fisik. Triger utama dari warga yang melakukan login dan mengisi form pindah jiwa.

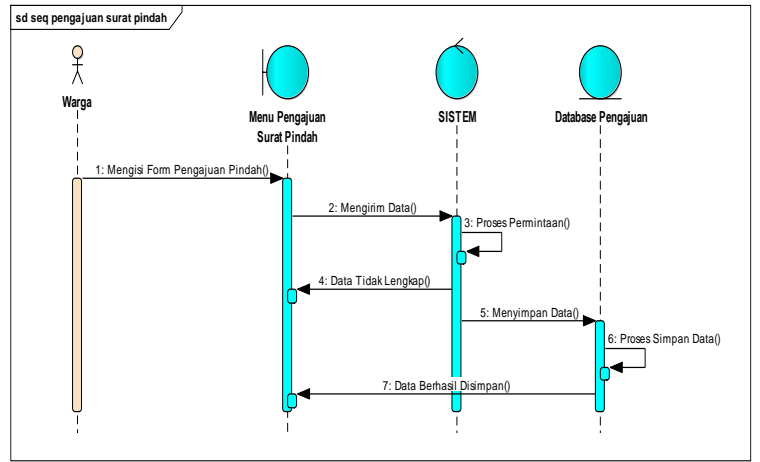

Sumber: Sismadi(2020)

Gambar 9. Sequence diagram pengajuan mutasi

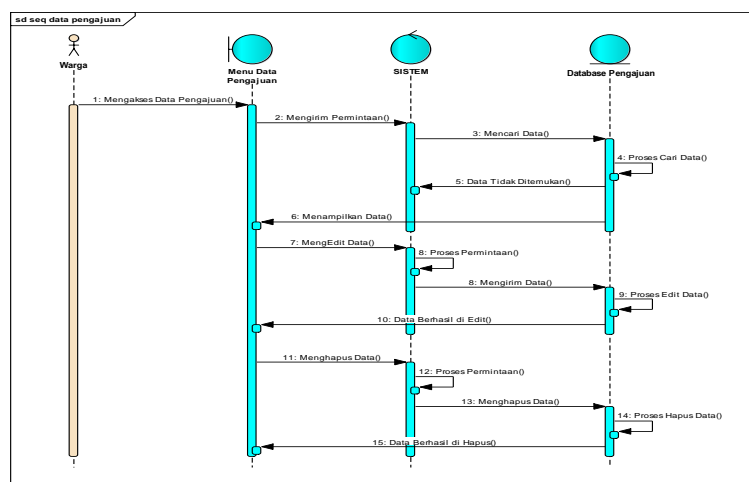

Sumber: Sismadi(2020)

Gambar 10. Sequence diagram ubah ajuan mutasi

\section{Pengguna sebagai pengelola sistem dalam hal ini petugas disdukcapil}

Pengguna yang diwakilkan oleh petugas disdukcapil sebagai pengelola sistem memiliki fitur dan akses jauh lebih besar, dapat juga disebut sebagai administrasi yang memiliki peran menyeluruh dari sistem yang dibuat. Berikut desain dari admin atau petugas disdukcapil.

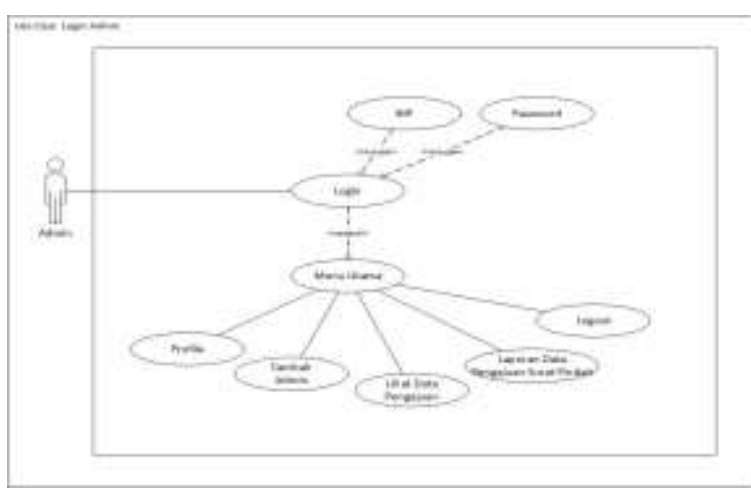

Sumber: Sismadi(2020)

Gambar 11. Use case login petugas disdukcapil
Pada gambar 11, use case dari pengelola sistem. Tergambar bahwa pengelola dapat melakukan login sebagai autentifikasi bahwa yang masuk kedalam sistem memang petugas yang memiliki hak untuk mengelola sistem. Petugas dapat mengelola profil, menambah petugas baru, melihat ajuan masyarakat yang akan pindah jiwa ataupun datang, mengelola laporan sewaktu-waktu diminta oleh pihak yang berwenang.

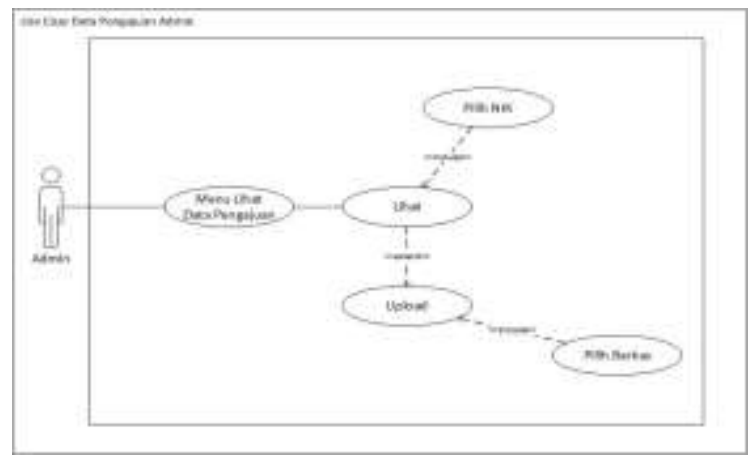

Sumber: Sismadi(2020)

Gambar 12. Use case melihat ajuan mutasi

Hak akses pengelola sistem pada gambar 12, digunakan untuk melakukan validasi ajuan dari warga masyarakat yang akan pindah domisili. Pengelola melakukan upload data untuk diintegrasikan kebagian lain.

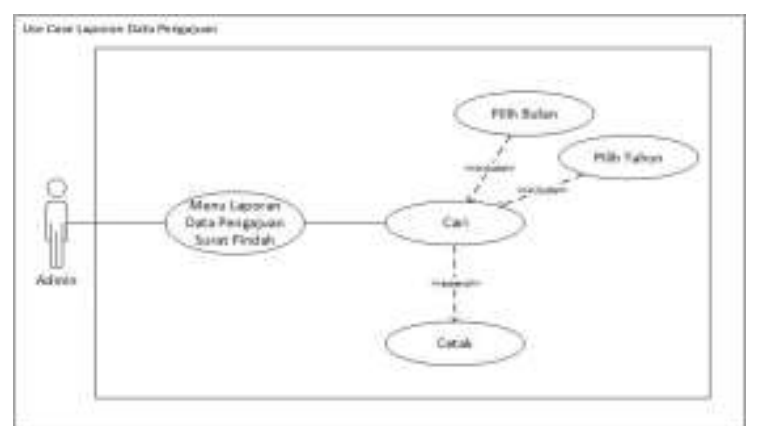

Sumber: Sismadi(2020)

Gambar 13. Use case laporan secara periodik

Laporan atau reporting digunakan untuk merekapitulasi jumlah warga yang pindah jiwa ataupun kedatangan jiwa. Dari hasil laporan dapat dijadikan perencanaan kedepan, misal bila laporan tergambar banyak warga pindah jiwa maka kemungkinan terdapat sesuatu yang kurang ataupun bila banyak warga yang datang kewilayah tersebut kemunginan ada sesuatu yang menarik diwilayah tujuan. 


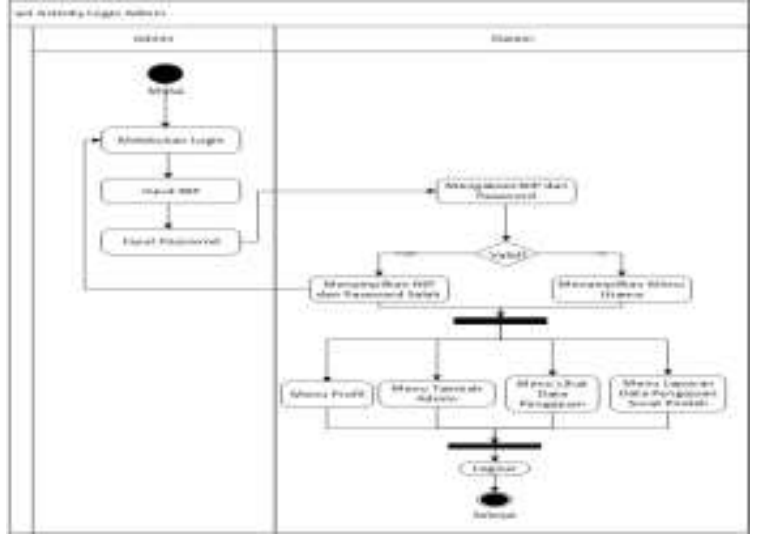

Sumber: Sismadi(2020)

Gambar 14. Activity diagram petugas disdukcapil

Berdasarkan gambar 14, aktifitas dari petugas setelah melakukan login kedalam sistem tergambar aktifitas apa saja yang dimiliki petugas disdukcapil, antara lain update profil, melihat data ajuan mutasi, dan membuat laporan secara periodik.

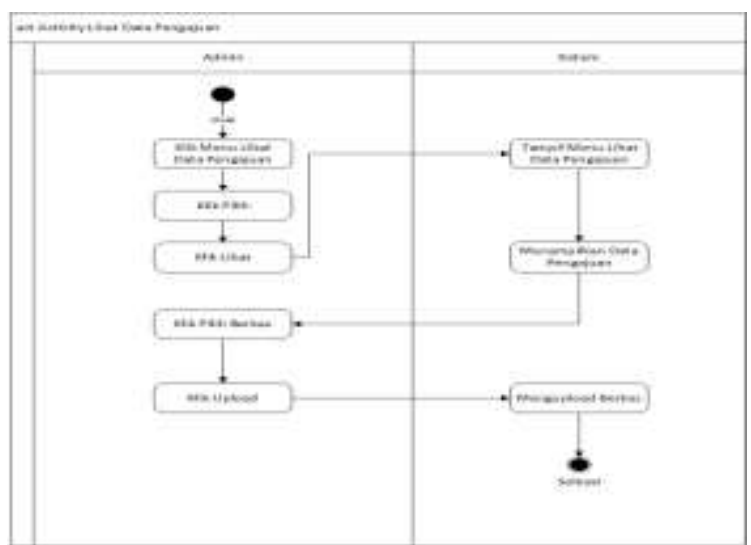

Sumber: Sismadi(2020)

Gambar 15. Activity diagram ajuan mutasi warga

Aktifitas pengajuan data, petugas dapat melakukan validasi dokumen yang ada. Pertama petugas mencek dokumen berdasarkan NIK dan sistem menampilkan data detail, kemudian mengupload data dokumen ajuan.

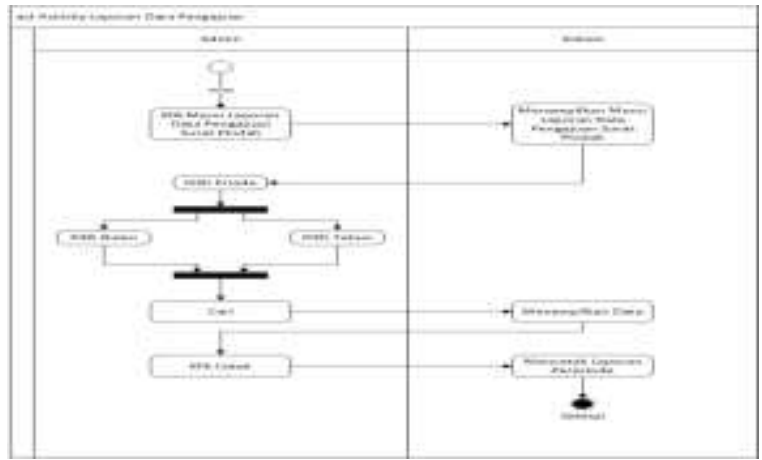

Sumber: Sismadi(2020)

Gambar 16. Activity diagram laporan

Laporan rekapitulasi mutasi dalam bulan dan bahkan tahun dapat dilihat dan dapat dijadikan koreksi dari sebuah kebijakan pemerintah lokal, baik untuk berbenah diri ataupun sebagai parameter kenyamanan suatu daerah untuk menetap.

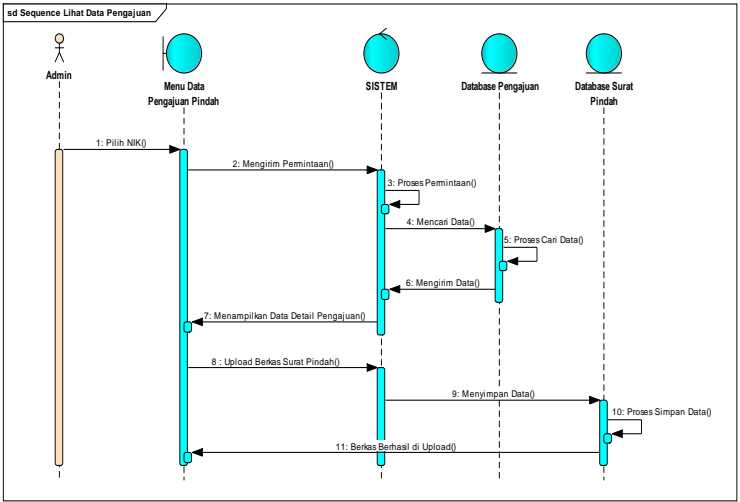

Sumber: Sismadi(2020)

Gambar 17. Sequence diagram cek ajuan mutasi

Validasi ajuan mutasi sangat penting untuk mencek memenuhi syarat ataupun tidak memenuhi bagi masyarakat yang akan pindah dan atau datang kewilayah bogor khususnya kota. Pada gambar 17, menerangkan alur kerja dari sistem.

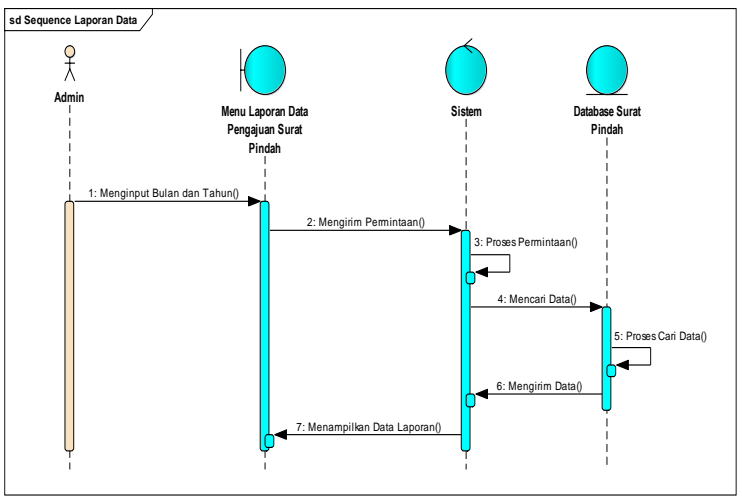

Sumber: Sismadi(2020)

Gambar 18. Sequence diagram cetak laporan

Sequence diagram gambar 18, menerangkan kerja secara urut pada proses pembuatan laporan, baik laporan bentuk digital ataupun bentuk cetakan hardcopy.

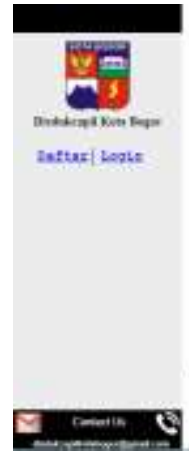

Dinas Kepesdutakan dan Pencatatan Sipii

Sumber: Sismadi(2020)

Gambar 19. Halaman index 
Desain visual pada gambar 19, adalah halaman index dari sistem yang dibuat. Disana terdapat dua buah link untuk daftar dan login, setiap pengguna wajib melakukan login masuk sebagai syarat berhak atau tidaknya pengguna.

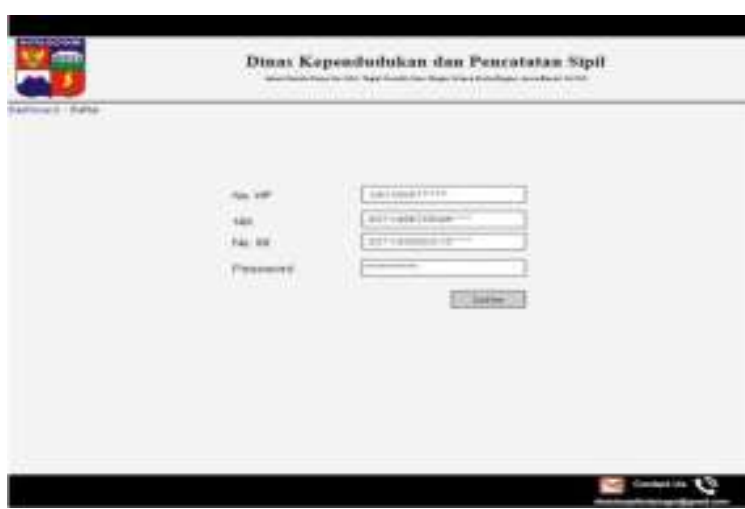

Sumber: Sismadi(2020)

Gambar 20. Pendaftaran

Pada gambar 20, bentuk visual hasil rancangan untuk pendaftaran pengguna. Form isian yang disediakan antara lain, nomer handphone, NIK sebagai perwakilan user untuk keperluan login kedalam sistem, nomer KK dan sandi. Setelah pengguna berhasil mendaftar maka pengguna dapat melakukan login kedalam sistem.

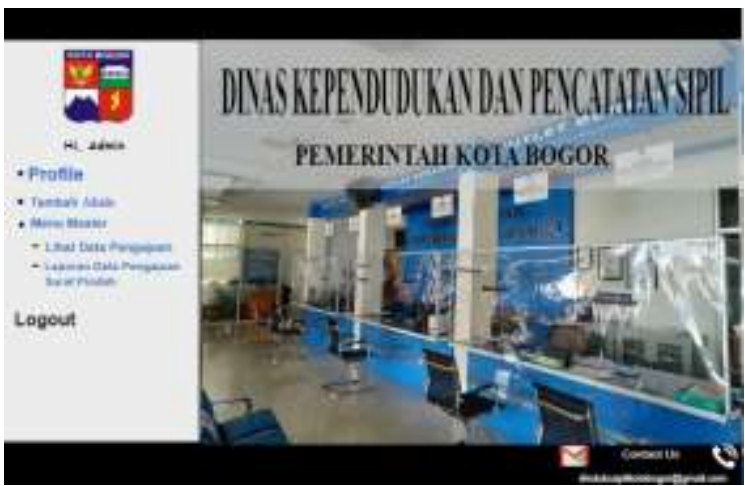

Sumber: Sismadi(2020)

Gambar 21. Dashboard pengelola

Setelah pengguna terutama pengelola sistem berhasil login maka akan terlihat view seperti terdapat pada gambar 21, disana terdapat link profil untuk dapat dilakukan update, menu master yang memberikan hak khusus untuk pengelola yang tidak terdapat pada pengguna sebagai warga yang mengajukan mutasi pindah. Pada menu master terdapat dua menu yaitu, lihat pengajuan yang berisi data ajuan masyarakat untuk dilakukan validasi keabsahan dokumen, laporan data pengajuan surat pindah, pada link ini dapat dilakukan pencetakan data sesuai kriteria yang telah disediakan oleh sistem yang dibangun. Link logout digunakan untuk keluar dari sistem, hal ini penting agar session ataupun cookies benar-benar bersih, sehingga sewaktu ada petugas lain menggunakan komputer tersebut memang benarbenar menggunakan login sendiri, sehingga sistem lebih aman.

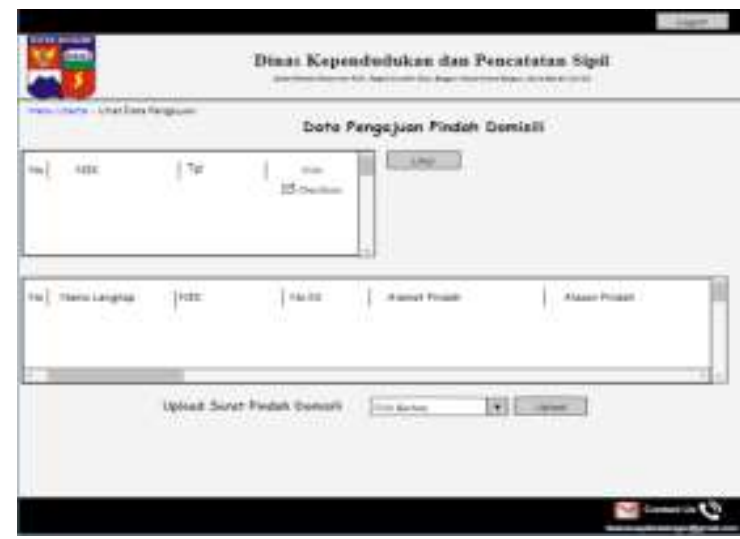

Sumber: Sismadi(2020)

Gambar 22. Data ajuan mutasi

View gambar 22, bentuk visual dari pengajuan pindah domisili kewilayah lain. Kolom paling atas menunjukkan banyaknya data yang sedang mengajukan mutase, dan kotak paling bawah berisi detil informasi dari ajuan mutase, yang berisi nama, NIK, nomer KK, alamat baru dan alasan pindah jiwa. Field alasan pindah sengaja diberikan sebab dikemudian hari dapat dilihat dan dikelompokkan berdasarkan alasan yang ada, kemudian ada kemungkinan dapat dijadikan koreksi kebijakan yang telah berlaku ataupun perencanaan kedepan.

Dari pembahasan tersebut dapat memberikan gambaran, bahwa mengkonversi cara kerja dari konvensional menjadi terdigital memberikan banyak kemudahan, efisiensi waktu dan ketelitian yang tinggi serta memberikan kemudahan dalam hal pengarsipan data penduduk.

\section{KESIMPULAN}

Dari paparan rancangan dan hasil penelitian, dapat ditarik kesimpulan bahwa perpindahan pola kerja dari manual menjadi terdigitalisasi dengan bantuan komputer dengan basis web terbukti dapat meringankan kerja petugas disdukcapil dalam melayani keperluan mutasi dari masyarakat. Tumpukan dokumen mutasi warga dapat dihilangkan, ketidak standar informasi tulisan tangan sebelum konversi sistem dapat dihilangkan sehingga diperoleh data yang akurat. Pada sisi lain yaitu masyarakat dapat memantau perkembangan ajuan mutasinya. Untuk pengembangan selanjutnya sistem ini dapat diterapkan dikelurahan/desa dalam misi melayani ajuan data untuk masyarakat, bahkan dapat diimplementasikan pada sistem androids. 


\section{REFERENSI}

Daud, N., \& Rusli, H. (2010). Implementing Rapid Application Development (RAD) methodology in developing practical training application system, 3, 1664-1667. https://doi.org/10.1109/ITSIM.2010.5561634

Delima, R., Santosa, H. B., \& Purwadi, J. (2017). Development of Dutatani Website Using Rapid Application Development. IJITEE (International Journal of Information Technology and Electrical Engineering), 1(2), 36-44. https://doi.org/10.22146/ijitee.28362

Dhanotia, S., \& Goyal, R. (2012). Rapid Application Development (Rad) Approach with Halt Points, 1(May).

Haris, A., Jatmiko, W., \& Wibisono, A. (2013). ANALYSIS OF QUALITY ASSURANCE ON SISTEM INFORMASI ZAKAT (SIZAKAT) THROUGH SOFTWARE TESTING. Jurnal Sistem Informasi, 9(2), 8291. https://doi.org/10.21609/jsi.v9i2.355

Ifeanyi Cosmas, N. (2018). Transitions in System Analysis and Design Methodology. American Journal of Information Science and Technology, 2(2), 50. https://doi.org/10.11648/j.ajist.20180202.14

Mishra, A., \& Dubey, D. (2013). A Comparative Study of Different Software Development Life Cycle Models in Different Scenarios. International Journal of Advance Research in Computer Science and Management Studies, 1(5), 2321-7782. Retrieved from http://www.ijarcsms.com/docs/paper/volume1/ issue5/V1I5-0008.pdf

Mueller, H. B. (2020). MySQL Database Service. Retrieved October 12, 2020, from https://www.oracle.com/id/mysql/

Naik, P., \& Naik, G. (2019). Enhancing PHP Coding with CodeIgniter - Hands-on Experience with CodeIgniter.

Nidhra, S., \& Dondeti, J. (2012). How to Write a L iterature $\mathrm{R}$ eview. Project Management Journal, 2(2), 29-50.

Sismadi. (2020). Sistem Manajemen Perniagaan Kaos Sablon Dengan Metode RAD Berbasis Web. JARTIKA Jurnal Riset Teknologi Dan Inovasi Pendidikan, 3(2), 234-246. https://doi.org/10.36765/jartika.v3i2.256

Suhartono, Astuti, R. D., Sfenrianto, S., Mustofa, M., Andriyani, D., \& Kaburuan, E. R. (2018). Development of 3D Solar System Application Using RAD Model for Elementary Schools. In 2018 International Conference on Orange Technologies (ICOT) (pp. 1-4). https://doi.org/10.1109/ICOT.2018.8705879

Undang Undang No.25 Tahun 2009 Tentang
Pelayanan Publik. (2009). Retrieved July 12, 2020, from http://pn-kediri.go.id/files/Standar Pelayanan/UU_25_2009.pdf 